\title{
Analisis Efektivitas, Kontribusi dan Laju Pertumbuhan PBBKB Terhadap PAD Sumatera Selatan
}

\author{
Vhika Meiriasari ${ }^{1}$, \\ Mutiara Kemala Ratu ${ }^{2}$ \\ ${ }^{1}$ Fakultas Ekonomi, Universitas Indo Global Mandiri \\ Email : vhikams@uigm.ac.id \\ ${ }^{2}$ Fakultas Ekonomi, Universitas Indo Global Mandiri \\ Email : mutiarakemala.ratu@uigm.ac.id
}

\begin{abstract}
Penelitian ini bertujuan untuk menganalisis efektivitas, kontribusi dan laju pertumbuhan pemungutan pajak bahan bakar kendaraan bermotor terhadap pendapatan asli daerah di Sumatera Selatan. Pajak Bahan Bakar Kendaraan Bermotor (PBBKB) dianggap sangat berpotensi untuk meningkatkan PAD, dimana salah satu sumber penerimaan PAD berasal dari pajak daerah salah satunya berasal dari PBBKB. Untuk daerah Sumatera Selatan, realisasi Pajak Bahan Bakar Kendaraan Bermotor (PBBKB) mengalami ketidakstabilan ditiap tahunnya, pada tahun 2014 sebesar Rp. 591.598.965.632, kemudian mengalami peningkatan pada tahun 2015 sebesar Rp 610.577.042.978, lalu menurun pada tahun 2016 menjadi Rp 513.205.513.586. Sedangkan ditahun 2017 mengalami peningkatan kembali menjadi Rp 670.559.294.854 dan ditahun 2018 menjadi $R p$ 838.900.055.118. Namun kenaikan tersebut belum mencapai target yang diinginkan. Metode analisis yang digunakan dalam penelitian ini adalah analisis data desktiptif kuantitatif. Dengan periode penelitian dari tahun 2014-2018. Hasil penelitian menunjukkan efektivitas pemungutan pajak bahan bakar kendaraan bermotor dari tahun 2014 sampai tahun 2018 sudah efektif, walaupun di tahun 2015 dan 2016 mengalami penurunan penerimaan PBBKB. Kontribusi pajak bahan bakar kendaraan bermotor dari tahun 2014 sampai tahun 2018 sudah cukup berkontribusi dalam meningkatkan PAD provinsi sumatera selatan. Sedangkan Laju Pertumbuhan pemungutan pajak bahan bakar kendaraan bermotor dari tahun 2014 sampai tahun 2018 sangat berfluktuatif. Selama tahun 2014 sampai tahun 2016 mengalami penurunan yang drastis dikarenakan selama tiga tahun berturut-turut realisasi penerimaan Pajak Bahan Bakar Kendaraan Bermotor tidak mencapai target. Baru di tahun 2017, laju pertumbuhan Pajak Bahan Bakar Kendaraan Bermotor mengalami kenaikan.
\end{abstract}

Keywords: Efektivitas, Kontribusi, Laju Pertumbuhan, PBBKB, PAD

\section{PENDAHULUAN}

Pendapatan Asli Daerah merupakan pendapatan terpenting yang digunakan untuk membiayai penyelengaraan kegiatan daerah dan pembangunan daerah, oleh karena itu, pelaksanaan dan pengelolaannya harus dilakukan dengan baik, hal ini dibutuhkan berbagai kebijakan yang lebih komprehensif, efektif dan efisien guna mencapai tujuan daerah yang maksimal (Winarso, 2015).

Pajak daerah menurut Undang-Undang Nomor 28 Tahun 2009 adalah kontribusi wajib kepada daerah yang terutang oleh orang pribadi atau badan yang bersifat memaksa berdasarkan undang-undang, dengan tidak mendapatkan imbalan secara langsung dan digunakan untuk keperluan daerah bagi sebesar-besarnya kemakmuran rakyat. Dengan demikian, pajak daerah merupakan pajak yang ditetapkan oleh pemerintah daerah dengan peraturan daerah, yang wewenang pemungutannya dilaksanakan oleh pemerintah daerah dan hasilnya digunakan untuk membiayai pengeluaran pemerintahan dan pembangunan di daerah. Dalam rangka meningkatkan pelayanan kepada masyarakat dan kemandirian daerah, daerah diperbolehkan melakukan perluasan objek pajak daerah dan retribusi daerah dan pemberian diskresi dalam penetapan tarif perluasan objek pajak yang belum diusahakan oleh negara.

Berdasarkan Undang-Undang Nomor 28 Tahun 2009 tentang Pajak Daerah dan Retribusi Daerah, pajak daerah dibedakan menjadi dua jenis yaitu pajak provinsi dan pajak kabupaten. Pajak Provinsi antara lain : Pajak kendaraan bermotor, Bea balik nama kendaraan bermotor, pajak bahan bakar kendaraan bermotor (PBBKB), pajak air permukaan dan pajak rokok. Sedangkan pajak kabupaten antara lain : pajak hotel, pajak restoran, pajak hiburan, pajak reklame, pajak penerangan jalan, pajak 
mineral bukan logam dan batuan, pajak parker, pajak sarang burung walet, pajak bumi dan bangunan pedesaan dan perkotaan, bea perolehan ha katas tanah dan bangunan.

Menurut Undang-Undang Nomor 28 Tahun 2009, Bahan bakar kendaraan bermotor adalah semua jenis bahan bakar cair atau gas yang digunakan untuk kendaraan bermotor. Tambahan kata gas karena mengikuti perkembangan zaman. Pajak Bahan Bakar Kendaraan Bermotor adalah pajak atas bahan bakar yang disediakan atau digunakan untuk kendaraan bermotor seperti bensin (premium, pertamax plus, bio solar dan bahan bakar kendaraan bermotor lainnya). Hingga saat ini, dengan pertimbangan bahwa negara Indonesia belum memiliki kemampuan teknologi untuk mengeksplorasi, mengeksploitasi, dan mengolah hasil minyak, serta belum memiliki modal dan sumber daya manusia yang memadai, maka perusahaan tambang minyak masih diusahakan dalam bentuk kerjasama dengan investor (Ermadiani et al., 2018). Berdasarkan Undang - Undang No 22 Tahun 2001 tentang Minyak dan Gas Bumi kerjasama dalam bentuk kerjasama kontrak production sharing (kontrak bagi hasil) dalam kegiatan Eksplorasi dan Eksploitasi yang lebih menguntungkan Negara dan hasilnya dipergunakan untuk sebesar-besar kemakmuran rakyat.

Salah satu yang dianggap sangat berpotensi untuk meningkatkan PAD adalah Pajak Bahan Bakar Kendaraan Bermotor (PBBKB). Hal ini dapat kita sadari bahwa jumlah kendaraan bermotor setiap tahun mengalami peningkatan. Apabila jumlah kendaraan bermotor di jalan bertambah, maka kebutuhan atas bahan bakar kendaraan bermotor pun meningkat (Samudra, 2016).

Namun penerimaan daerah atas PBBKB belum maksimal terlihat beberapa tahun terakhir, dari tahun 2014 - 2018, realisasi Pajak Bahan Bakar Kendaraan Bermotor (PBBKB) selalu mengalami ketidakstabilan ditiap tahunnya, seperti pada tahun 2014 yang memperoleh sebesar Rp. 591.598.965.632, kemudian mengalami peningkatan pada tahun 2015 sebesar Rp 610.577.042.978, lalu menurun kembali pada tahun 2016 menjadi Rp 513.205.513.586. Sedangkan ditahun 2017 mengalami peningkatan kembali menjadi Rp 670.559.294.854 dan ditahun 2018 menjadi Rp 838.900.055.118 akan tetapi jumlah kenaikan tersebut belum mencapai target yang diinginkan. Setiap perusahaan diharuskan mewajibkan membayar pajak 7,5\% (tujuh setengah persen) dari total banyaknya penggunaan bahan bakar yang dipakai ditiap bulannya. Menurut Badan Pengatur Hilir Minyak dan Gas (BPH Migas), saat ini ada 197 perusahaan yang menggunakan bahan bakar minyak di Indonesia. Sedangkan untuk Provinsi Sumatera Selatan ada 42 perusahaan namun yang aktif hanya 35 perusahaan saja.

\section{Gambar 1}

Realisasi Pajak Bahan Bakar Kendaraan Bermotor Provinsi Sumatera Selatan Tahun 2014-2018

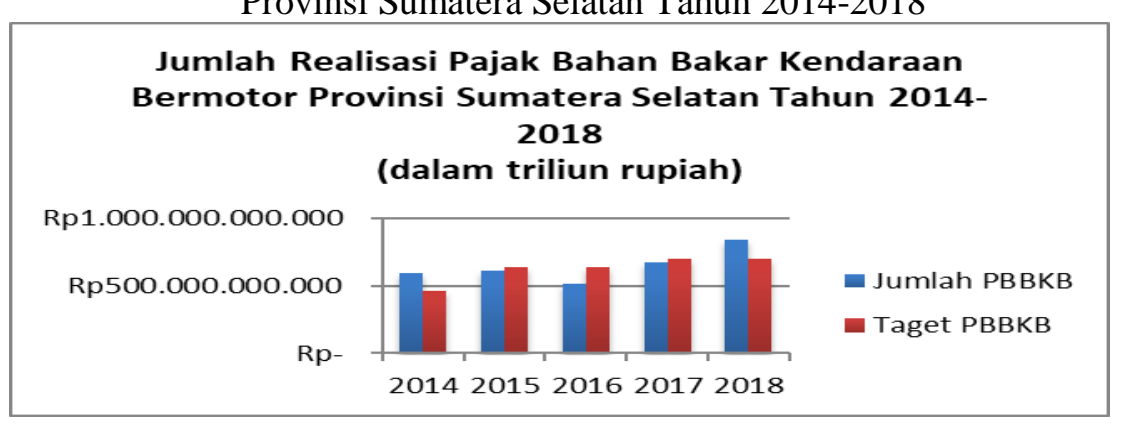

Sumber: Badan Pendapatan Daerah Provinsi Sumatera Selatan (2020), diolah

Badan Usaha yang melakukuan kegiatan usaha penjualan, pembelian, ekspor dan impor Bahan bakar Minyak, Bahan Bakar Gas, Bahan Bakar Lain dan/atau Hasil Olahan dapat melaksanakan Kegiatan Usaha Hilir Gas adalah Badan Usaha Milik Negara (BUMN), Badan Usaha Milik Daerah (BUMD), Koperasi atau Usaha Kecil dan Badan Usaha Swasta (Swasta). Badan Usaha yang pelaksanakan kegiatan Usaha Hilir Gas Bumi wajib membayar pajak, termasuk dengan pungutan lain atas impor, cukai, pajak daerah dan retribusi daerah, serta kewajiban lain sesuai dengan ketentuan peraturan perundang-undangan yang berlaku.

Menurut (Mardiasmo, 2018) Efektivitas merupakan ukuran berhasil tidaknya suatu organisasi mencapai tujuannya. Apabila suatu organisasi berhasil mencapai tujuan, maka organisasi tersebut dikatakan telah berjalan dengan efektf. Semakin tinggi rasio efektivitas maka menggambarkan kemampuan daerah yang semakin baik. Dalam penelitian ini, efektivitas diukur dengang realisasi penerimaan PBBKB dibagi dengan target penerimaan PBBKB dikali dengan 100\%. 
Kontribusi adalah sesuatu yang diberikan bersama-sama kepada perkumpulan dan sebagainya untuk bertujuan tertentu. Kontribusi merupakan alat analisis yang digunakan untuk mengetahui berapa besar peranan atau proporsi penerimaan pajak terhadap Pendapatan Asli Daerah di Provinsi Sumatera Selatan (Elim et al., 2015).

Sedangkan Laju pertumbuhan ekonomi adalah proses kenaikan output perkapita dalam jangka panjang (I. \& F. H. Rahmadani, 2018). Jika diterapkan dalam Pajak Bahan Bakar Kendaraan Bermotor, maka laju pertumbuhan adalah proses kenaikan penerimaan pajak bahan bakar kendaraan bermotor dalam jangka panjang. Dengan kata lain, untuk mengetahui apakah pemerintah daerah selama beberapa periode anggaran, kinerja anggarannya mengalami pertumbuhan secara positif atau negatif.

PBBKB digolongkan menjadi pajak provinsi. Jika penerimaan daerah, yaitu antara daerah tingkat provinsi, daerah kota dan kabupaten tidak seimbang, tentunya tidak mendukung perkembangan otonomi daerah, terutama bagi pembangunan daerah lebih dititikberatkan pada kota/kabupaten. (Samudra, 2016).

Berdasarkan gambar 1 yang sudah dijelaskan sebelumnya, dimana realisasi pajak bahan bakar kendaraan bermotor di Provinsi Sumatera Selatan dapat dikatakan mengalami ketidakstabilan disetiap tahunnya dan juga sering tidak mencapai target, padahal PBBKB salah satu yang dianggap sangat berpotensi untuk meningkatkan PAD. dikarenakan dapat kita sadari bahwa jumlah kendaraan bermotor setiap tahun mengalami peningkatan. Apabila jumlah kendaraan bermotor di jalan bertambah, maka kebutuhan atas bahan bakar kendaraan bermotor pun meningkat. Oleh karena itu, penulis tertarik untuk meneliti "Analisis Efektivitas, Kontribusi dan Laju Pertumbuhan Pemungutan Pajak Bahan Bakar Kendaraan Bermotor Terhadap Pendapatan Asli Daerah (PAD) Provinsi Sumatera Selatan".

\section{KAJIAN PUSTAKA DAN PEGEMBANGAN HIPOTESIS}

Menurut (Mardiasmo, 2018) Efektivitas merupakan tingkat capaian yang menunjukkan apakah besarnya realisasi penerimaan Pajak Bahan Bakar Kendaraan Bermotor sesuai dengan target penerimaan pajak bahan bakar kendaraan bermotor. Adapun Rumus menghitungnya :

$$
\text { Efektivitas }=\frac{\text { Realisasi Penerimaan PBBKB }}{\text { Target Penerimaan PBBKB }} \times 100 \%
$$

Adapun kriteria penilaian efektivitas pemungutan Pajak Bahan Bakar Kendaraan Bermotor adalah semakin tinggi rasio efektivitas maka menggambarkan kemampuan daerah yang semakin baik yang di tunjukkin pada tabel di bawah ini :

\begin{tabular}{|c|c|}
\hline Presentase & Kriteria \\
\hline$>100 \%$ & Sangat Efektif \\
\hline $90-100 \%$ & Efektif \\
\hline $80-90 \%$ & Cukup Efektif \\
\hline $60-80 \%$ & Kurang Efektif \\
\hline$<60 \%$ & Tidak Efektif \\
\hline
\end{tabular}

Menurut Elim et al., (2015) Kontribusi adalah sesuatu yang diberikan bersama-sama kepada perkumpulan dan sebagainya untuk bertujuan tertentu. Kontribusi Pajak Bahan Bakar Kendaraan Bermotor (PBBKB) adalah sumbangan Pajak Bahan Bakar Kendaraan Bermotor terhadap Pendapatan Asli Daerah yang digunakan untuk mengetahui seberapa besar peranan PBBKB dalam meningkatkan pendapatan asli daerah, sehingga akan dapat memberikan gambaran yang lebih jelas mengenai tindakan/ kebijakan apa saja yang harus diperhatikan PBBKB sebagai usaha peningkatan peranya terhadap PAD. Kontribusi yang digunakan untuk mengetahui sejauh mana pajak daerah memberikan sumbangan dalam penerimaan PAD, Rumus kontribusi menurut (Mardiasmo, 2018): 


\section{Kontribusi PBBKB $=\frac{\text { Realisasi Penerimaan PBBKB }}{\text { Realisasi Penerimaan PAD }} \times 100 \%$}

Sedangkan kriteria dalam menilai kontribusi pemungutan Pajak Bahan Bakar Kendaraan Bermotor (PBBKB) adalah sebagai berikut:

Tabel 2. Rasio Kriteria Kontribusi

\begin{tabular}{ll}
\hline \multicolumn{1}{c}{ Presentase } & \multicolumn{1}{c}{ Kriteria } \\
\hline $\mathrm{q} 0,00 \%-10 \%$ & Tidak Berkontribusi \\
\hline $10,10 \%-20 \%$ & Kurang Berkontribusi \\
\hline $20,10 \%-30 \%$ & Cukup Berkntribusi \\
\hline $30,10 \%-40 \%$ & Berkontribusi \\
\hline $40,10 \%-50 \%$ & Sangat Berkontribusi \\
\hline Sumber: (Fitri \& Fajriana, 2016)
\end{tabular}

Laju pertumbuhan PBBKB adalah selisih dari realisasi penerimaan PBBKB tahun tertentu dengan realisasi penerimaan $\mathrm{PBBKB}$ pada tahun sebelumnya dibagi dengan realisasi penerimaan PBBKB pada tahun sebelumnya. Adapun rumus untuk menghitung laju pertumbuhan pemungutan pajak bahan bakar kendaraan bermotor menurut (I. \& F. H. Rahmadani, 2018) :

Keterangan :

$$
\mathbf{G x}=\frac{\mathbf{X t}-\mathbf{X}(\mathbf{t}-\mathbf{1})}{X(t-\mathbf{1})} \times \mathbf{1 0 0} \%
$$

Gx : Pertumbuhan pajak PBBKB per tahun

$\mathrm{Xt} \quad$ : Realisasi penerimaan PBBKB tahun tertentu

$\mathrm{X}(\mathrm{t}-1)$ : Realisasi penerimaan PBBKB pada tahun sebelumnya

Dibawah ini merupakan kriteria penilaian laju pertumbuhan dapat dilihat sebagai berikut :

\begin{tabular}{ll}
\multicolumn{2}{c}{ Tabel 3. Rasio Kriteria Laju Pertumbuhan } \\
\hline \multicolumn{1}{c}{ Presentase } & \multicolumn{1}{c}{ Kriteria } \\
\hline $85 \%-100 \%$ & Sangat Berhasil \\
\hline $70 \%-85 \%$ & Berhasil \\
\hline $55 \%-70 \%$ & Cukup Berhasil \\
\hline $30 \%-55 \%$ & Kurang Berhasil \\
\hline Kurang Dari 30\% & Tidak Berhasil \\
\hline Sumber $:$ Supriadi (2020)
\end{tabular}

\section{METODE PENELITIAN}

Penelitian ini dilakukan di Badan Pendapatan Daerah Provinsi Sumatera Selatan yang beralamatkan pada Jl. POM IX Kelurahan Lorok Pakjo Kecamatan Ilir Barat. I, Kota Palembang, Sumatera Selatan 30137. Jenis data yang digunakan dalam penelitian ini adalah data sekunder. Menurut (Azwar, 2015) Data Sekunder merupakan data yang diperoleh dari pihak lain yang tidak langsung diperoleh oleh peneliti dari subjek penelitinya dan biasanya berwujud data dokumentasi atau data laporan yang telah tersedia. Data sekunder dalam penelitian ini yaitu data Target dan Realisasi Pajak Bahan Bakar Kendaraan Bermotor (PBBKB) tahun 2014 hingga 2018, data Realisasi Penerimaan Pendapatan Asli Daerah Provinsi Sumatera Selatan tahun 2014 hingga 2018, data di dapat dari Badan Pendapatan Daerah (BAPENDA) Provinsi Sumatera Selatan.

Populasi dalam penelitian ini adalah 42 perusahaan niaga umum yang ada di Sumatera Selatan yaitu pemungutan pajak bahan bakar kendaraan bermotor pada perusahaan niaga umum. Penentuan sampel dalam penelitian ini dilakukan dengan jenis Non-Probability Sampling. Teknik Non-Probability Sampling yang dipilih yaitu sampling jenuh yaitu metode penarikan sampel bila semua anggota populasi dijadikan sampel. Oleh karena itu, sampel yang digunakan dalam penelitian ini adalah 35 perusahaan niaga umum yang ada di Sumatera Selatan. 
Teknik analisis data yang diguanakan dalam penelitian ini adalah metode analisis deskriptif kuantitatif, merupakan suatu penelitian yang mempunyai tujuan untuk mendeskripsikan suatu fenomena, peristiwa, gejala, da kejadian yang terjadi secara faktual, sistematis serta akurat. Metode penelitian deskriptif kuantitatif bertujuan untuk menjelaskan suatu fenomena dengan menggunakan angka yang menggambarkan karakteristik subjek yang diteliti. Dalam penelitian ini efektivitas, kontribusi dan laju pertumbuhan telah dihitung dengan menggunakan rumus.

\section{HASIL DAN PEMBAHASAN}

Pajak Bahan Bakar Kendaraan Bermotor (PBBKB) menganut sistem pemungutan pajak Self Assesment System yakni Pemungutan Pajak Kendaraan Bermotor yaitu wajib pajak atau badan menentukan, menghitung, melaporkan sendiri besaran pajak yang terutang tersebut ke Badan Pendapatan Daerah (BAPENDA) Provinsi Sumatera Selatan, sehingga proses pendataan atau registrasi Pajak Bahan Bakar Kendaraan Bermotor (PBBKB) yakni dengan pengisian SPTPD bagi wajib pajak dan kemudian dibayarkan sendiri oleh wajib pajaknya kepada Badan Pendapatan Daerah Provinsi Sumatera Selatan.

Setelah proses pendapatan dilakukan oleh Wajib Pajak Bahan Bakar Kendaraan Bermotor (PBBKB) barulah tata cara penyetoran dan pelaporan PBBKB. Menurut undang-undang Nomor 28 Tahun 2009 Tata cara penyetoran Pajak Bahan Bakar Kendaraan (PBBKB) dilakukan oleh wajib pajak bahan bakar kendaraan bermotor (PBBKB) disetorkan paling lambat tanggal 25 (dua puluh lima) pada bulan berikutnya kepada kas negara, dengan melampirkan SSPD (Surat Setoran Pajak Daerah) kepada Badan Pendapatan Daerah Sumatera Selatan. Setelah menyampaikan SSPD wajib pajak wajib melaporkan atas penyetoran yang telah dilakukan kepada Badan Pendapatan Daerah Provinsi Sumatera Selatan ke Gubernur. Menurut Peraturan Daerah Provinsi Sumatera Selatan No. 03 Tahun 2011 tentang Pajak Daerah Penyedia Bahan Bakar Kendaraan Bermotor wajib mengisi dan menyampaikan SPTPD setiap bulan kepada Gubernur atau yang ditunjuk paling lambat tanggal 5 (lima) bulan berikutnya atas penjualan bahan bakar kendaraan bermotor.

\section{Efektivitas Pemunguntan Pajak Bahan Bakar Kendaraan Bermotor (PBBKB) Terhadap PAD}

Pemungutan Pajak Bahan Bakar Kendaraan Bermotor Pemerintah Daerah Provinsi Sumatera Selatan, tahun 2014 yang memperoleh sebesar Rp 591.598.965.632 dengan target Rp 460.079.000.000, kemudian mengalami peningkatan pada tahun 2015 sebesar Rp 610.577.042.978, meskipun tidak mencapai target $\mathrm{Rp}$ 640.000.000.000 lalu pada tahun 2016 mengalami penurunan penerimaan Pajak Bahan Bakar Kendaraan Bermotor (PBBKB) yang signifikan sebesar menjadi Rp 513.205.513.586 dengan target yang sama pada tahun sebelumnya yaitu sebesar Rp. 640.000.000.000. Sedangkan ditahun 2017 mengalami peningkatan kembali menjadi Rp 670.559.294.854 dengan target Rp. 697.000.000.000 dan ditahun 2018 kembali meningkat menjadi Rp 838.900.055.118 akan tetapi jumlah tersebut belum mencapai target yang di inginkan.

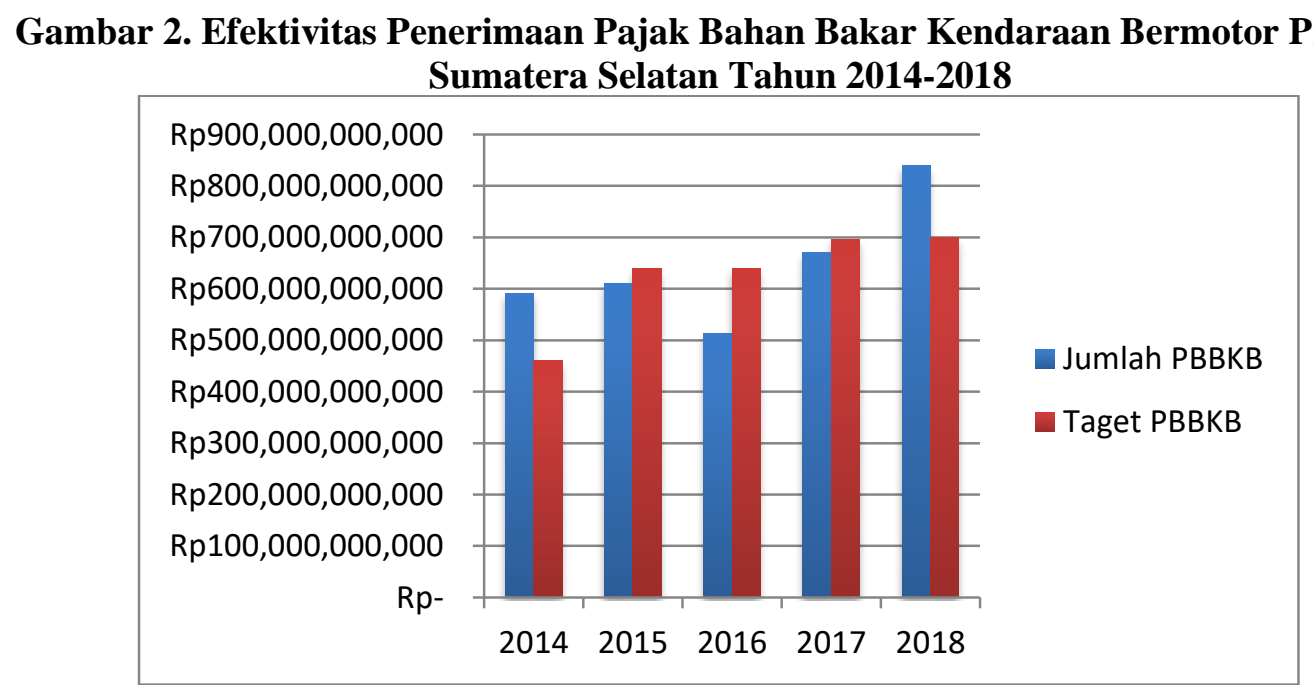

Sumber: Badan Pendapatan Daerah Provinsi Sumatera Selatan (2020), diolah 
Tabel 4. Realisasi Pajak Bahan Bakar Kendaraan Bermotor (PBBKB) Di Sumatera Selatan 2014-2018

\begin{tabular}{ccccc}
\hline Tahun & Target PBBKB & $\begin{array}{c}\text { Realisasi } \\
\text { PBBKB }\end{array}$ & $\begin{array}{c}\text { Presentas } \\
\mathbf{e}(\%)\end{array}$ & Kriteria \\
\hline 2014 & 460.079 .000 .000 & 591.598 .965 .632 & 128,59 & Sangat Efektif \\
\hline 2015 & 640.000 .000 .000 & 610.577 .042 .978 & 95,40 & Efektif \\
\hline 2016 & 640.000 .000 .000 & 513.205 .513 .586 & 80,19 & Cukup Efektif \\
\hline 2017 & 697.000 .000 .000 & 670.559 .294 .854 & 96,21 & Efektif \\
\hline 2018 & 700.000 .000 .000 & 838.900 .055 .118 & 119,84 & Sangat Efektif \\
\hline Sumber: Badan Pendapatan Daerah Provinsi Sumatera Selatan (2020), diolah
\end{tabular}

Perhitungan Efektivitas pemungutan pajak bahan bakar kendaraan bermotor sebagai berikut: Efektivitas Tahun $2014: \frac{591.598 .965 .632}{460.079 .000 .000} \times 100 \%=128,59 \%$

Efektivitas Tahun $2015: \frac{610.577 .042 .978}{640.000 .000 .000} \times 100 \%=95,40 \%$

Efektivitas Tahun $2016: \frac{513.205 .513 .586}{640.000 .000 .000} \times 100 \%=80,19 \%$

Efektivitas Tahun $2017: \frac{670.559 .294 .854}{697.000 .000 .000} \times 100 \%=96,21 \%$

Efektivitas Tahun $2018: \frac{838.900 .055 .118}{700.000 .000 .000} \times 100 \%=119,84 \%$

Berdasarkan persentase diatas yang didapatkan dengan menggunakan rumus sehingga tingkat efektivitas pajak bahan pakar kendaraan bermotor pada perusahaan niaga umum dalam peningkatan pendapatan asli daerah adalah pada tahun 2014 tingkat efektivitasnya berada pada sebesar 128,59\% dengan kriteria sangat efektif. Namun, pada tahun 2015 mengalami penurunan persentase sebesar 95,40\% tetapi masih dalam kriteria efektif. Di tahun 2016 kembali mengalami penurunan secara drastis dari tahun 2014, yaitu sebesar 80,19\% masih dengan kriteria cukup efektif. Penurunan tersebut disebabkan karena penetapan target penerimaan pada tahun tersebut terlalu tinggi dan penyebab lainnya seperti jatuhnya harga minyak (Fitri \& Fajriana, 2016).

Pada tahun 2017 presentase tingkat efektivitas pajak bahan bakar kendaraan bermotor mengalami kenaikkan persentase sebesar 96,21\% dalam kriteria efektif, dan pada tahun 2018 dinilai sangat efektif dengan presentase sebesar 119,84\%.

\section{Kontribusi Pemunguntan Pajak Bahan Bakar Kendaraan Bermotor (PBBKB) Terhadap PAD}

Gambar 3 Kontribusi Pemungutan Pajak Bahan Bakar Kendaraan Bermotor Provinsi Sumatera Selatan Tahun 2014-2018

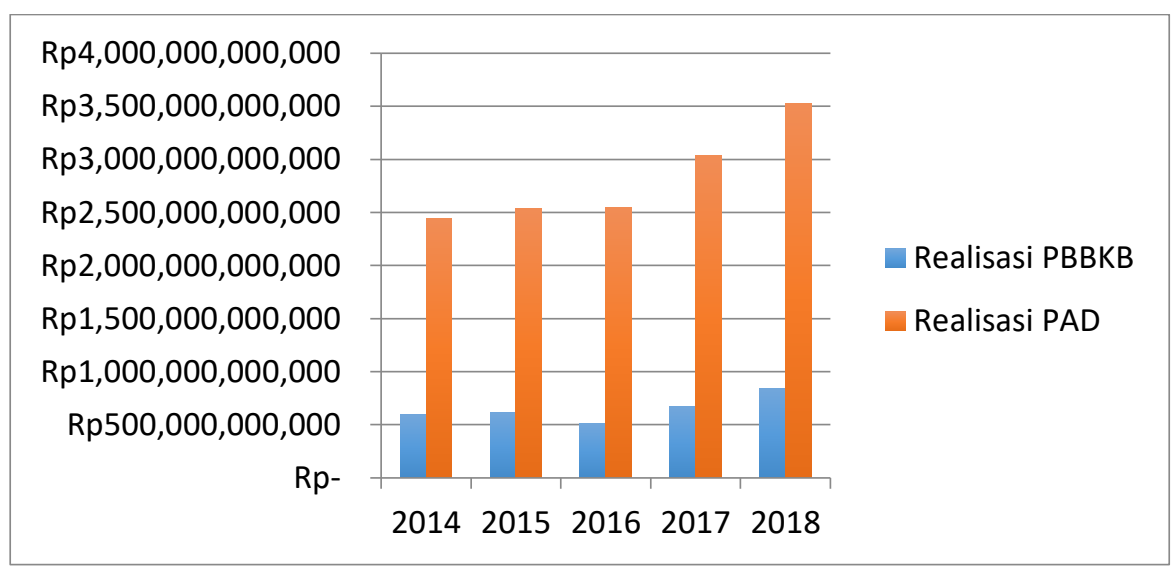

Sumber: Badan Pendapatan Daerah Sumatera Selatan 2020, diolah 
Tabel 5. Kontribusi Pemungutan Pajak Bahan Bakar Kendaraan Bermotor (PBBKB) Pada Perusahaan Niaga Umum Tahun 2014-2018

\begin{tabular}{ccccc}
\hline Tahun & $\begin{array}{c}\text { Realisasi } \\
\text { PBBKB }\end{array}$ & Realisasi PAD & $\begin{array}{c}\text { Presentas } \\
\text { e (\%) }\end{array}$ & Kriteria \\
\hline 2014 & 591.598 .965 .632 & $2.442 .673 .788 .768,86$ & 24,42 & Cukup Berkontribusi \\
\hline 2015 & 610.577 .042 .978 & $2.534 .526 .413 .315,20$ & 24,09 & Cukup Berkontribusi \\
\hline 2016 & 513.205 .513 .586 & $2.546 .177 .544 .346,66$ & 20,15 & Cukup Berkontribusi \\
\hline 2017 & 670.559 .294 .854 & 3.031 .633 .624 .303 & 22,11 & Cukup Berkontribusi \\
\hline 2018 & 838.900 .055 .118 & 3.528 .010 .712 .183 & 23,77 & Cukup Berkontribusi \\
\hline
\end{tabular}

Sumber: Badan Pendapatan Daerah Provinsi Sumatera Selatan (2020), diolah

Perhitungan kontribusi pemungutan pajak bahan bakar kendaraan bermotor sebagai berikut :

$$
\begin{aligned}
& \text { Tahun 2014: } \frac{591.598 .965 .632}{2.442 .673 .788 .768,86} \times 100 \%=24,42 \% \\
& \text { Tahun 2015: } \frac{610.577 .042 .978}{2.534 .526 .413 .315,20} \times 100 \%=24,09 \% \\
& \text { Tahun 2016: } \frac{513.205 .513 .586}{2.546 .177 .544 .346,66} \times 100 \%=20,15 \% \\
& \text { Tahun 2017: } \frac{670.559 .294 .854}{3.031 .633 .624 .303} \quad x 100 \%=22,11 \% \\
& \text { Tahun 2018: } \frac{838.900 .055 .118}{3.528 .010 .712 .183} \quad x 100 \%=23,77 \%
\end{aligned}
$$

Tingkat kontribusi pajak bahan pakar kendaraan bermotor pada perusahaan niaga umum dalam peningkatan pendapatan asli daerah adalah pada tahun 2014 tingkat kontribusinya berada pada 24,42\% dengan kriteria cukup berkontribusi. Namun, pada tahun 2015 mengalami penurunan persentase sebesar 24,09\% tetapi masih dalam kriteria cukup berkontribusi. Di tahun 2016 kembali mengalami penurunan secara drastis dari tahun 2014, yaitu sebesar 20,15\% masih dengan kriteria cukup berkontribusi. Penurunan tersebut disebabkan karena penetapan target penerimaan pada tahun tersebut terlalu tinggi dan penyebab lainnya seperti jatuhnya harga minyak serta juga sangat berpengaruh pada meningkatnya atau menurunnya tingkat efektivitas pajak bahan bakar kendaraan bermotor. Pada tahun 2017 presentase tingkat kontribusi pajak bahan bakar kendaraan bermotor mengalami kenaikkan presntase sebesar 22,11\% dalam kriteria cukup berkontribusi. Dan pada tahun 2018 juga dinilai cukup efektif dengan presentase sebesar $23,77 \%$.

Maka dapat dikatakan kontribusi pada Pemungutan Pajak Bahan Bakar Kendaraan Bermotor (PBBKB) pada perusahaan niaga umum dalam peningkatan Pendapatan Asli Daerah Provinsi Sumatera Selatan tahun 2014, 2015, 2016, 2017, dan 2018 adalah cukup berkontribusi. Walaupun cukup berkontribusi, harusnya masih dapat dimaksimalkan agar persentase kontribusi PBBKB bisa mencapai di atas 30\% tiap tahunnya. Dimana kriteria berkontribusi berada pada persentase di atas $40 \%$ dan kriteria sangat berkontribusi berada pada persentase di atas $50 \%$.

\section{Laju Pertumbuhan Pemunguntan Pajak Bahan Bakar Kendaraan Bermotor (PBBKB) Terhadap PAD}

Laju pertumbuhan ekonomi adalah proses kenaikan output perkapita dalam jangka panjang. Jika diterapkan dalam pajak bahan bakar kendaraan bermotor, laju pertumbuhan adalah proses kenaikan penerimaan pajak bahan kendaraan bermotor dalam jangka panjang. Perhitungan laju pertumbuhan pemungutan pajak bahan bakar kendaraan bermotor sebagai berikut :

Tahun $2014: G(2014)=\frac{591.598 .965 .632-508.333 .162 .553}{508.333 .162 .553} \times 100 \%=16,38 \%$ 
Tahun $2015: G(2015)=\frac{610.557 .042 .978-591.598 .965 .632}{591.598 .965 .632} \times 100 \%=3,20 \%$

Tahun $2016: G(2016)=\frac{513.205 .513 .586-610.557 .042 .978}{610.557 .042 .978} \times 100 \%=-15,94 \%$

Tahun $2017: G(2017)=\frac{670.559 .294 .854-513.205 .513 .586}{513.205 .513 .586} \times 100 \%=30,6 \%$

Tahun $2018: G(2018)=\frac{838.900 .055 .118-670.559 .294 .854}{670.559 .294 .854} \times 100 \%=25,1 \%$

Tabel 6. Laju Pertumbuhan Pemungutan Pajak Bahan Bakar Kendaraan Bermotor (PBBKB) Pada Perusahaan Niaga Umum Tahun 2014-2018

\begin{tabular}{cccc}
\hline Tahun & $\begin{array}{c}\text { Realisasi Penerimaan PBBKB } \\
(\text { RP) }\end{array}$ & $\begin{array}{c}\text { Laju Pertumbuhan } \\
\text { PBBKB (\%) }\end{array}$ & Kriteria \\
\hline 2013 & 508.333 .162 .553 & & \\
\hline 2014 & 591.598 .965 .632 & $16,38 \%$ & Tidak Berhasil \\
\hline 2015 & 610.557 .042 .978 & $3,2 \%$ & Tidak Berhasil \\
\hline 2016 & 513.205 .513 .586 & $-15,94 \%$ & Tidak Berhasil \\
\hline 2017 & 670.559 .294 .854 & $30,6 \%$ & Kurang Berhasil \\
\hline 2018 & 838.900 .055 .118 & $25,1 \%$ & Tidak Berhasil \\
\hline
\end{tabular}

Sumber: Badan Pendapatan Daerah Provinsi Sumatera Selatan (2020), diolah

Laju pertumbuhan pajak bahan bakar kendaraan bermotor dari tahun 2013-2018 mengalami fluktuasi. Pada tahun 2014 penerimaan laju pertumbuhannya mengalami peningkatan yang cukup besar yaitu sebesar 16,38 \%. Namun, tahun 2015 mengalami penurunan yang cukup tinggi dengan laju pertumbuhan hanya 3,2\%. Tahun 2016 bahkan laju pertumbuhannya $-15,94 \%$ tetapi tahun 2017 laju pertumbuhannya mengalami kenaikan yang cukup tinggi yaitu sebesar 30,6\%. Tingkat pertumbuhan yang berfluktuasi selama 3 tahun yaitu periode 2015-2017 ini diakibatkan oleh tidak tercapainya target penerimaan PBBKB. Sedangkan pada tahun 2018, walaupun laju pertumbuhannya turun ke angka $25,1 \%$ tetapi realisasi penerimaan PBBKB tercapai pada angka Rp. 838.900.055.188 mengalami kenaikan yang banyak dari realisasi tahun sebelumnya tahun 2017 yang tercapai pada angka Rp. 670.559.294.854. Dengan pertumbuhan yang fluktuatif, jika dilihat dari tabel kriteria bisa dikatakan laju pertumbuhannya belum berhasil.

\section{KESIMPULAN}

Berdasarkan penelitian yang telah dilakukan bahwa efektivitas pemungutan Pajak Bahan Bakar Kendaraan Bermotor (PBBKB) di provinsi Sumatera Selatan pada tabel 4 dari tahun 2014 hingga 2018 dinilai efektif karena rasio yang berada di atas $80 \%$. Hal ini membuktikan bahwa Badan Pendapatan Daerah Provinsi Sumatera Selatan dinilai efektif dalam mengelola penerimaan Pajak Bahan Bakar Kendaraan Bermotor (PBBKB). Penyebab dari tidak tercapainya target penerimaan Pajak Bahan Bakar Kendaraan Bermotor yang telah ditetapkan yakni tahun 2015 sampai dengan 2017 sebesar 95,40\%, 80,19\%, dan 96,21\% disebabkan penetapan target penerimaan pada tahun tersebut terlalu tinggi. Kontribusi pemungutan Pajak Bahan Bakar Kendaraan Bermotor (PBBKB) dapat dilihat pada tabel 5, dari tahun 2014 hingga 2018 dinilai cukup berkontribusi dalam penerimaan Pendapatan Asli Daerah Provinsi Sumatera Selatan dilihat dari besaran persentase yang stabil di angka terendah sebesar 20,15\% (tahun 2016) dan di angka tertinggi 24,42\% (tahun 2014). Sedangkan laju pertumbuhan pemungutan pajak bahan bakar kendaraan bermotor dari tahun 2014 -2018 pada tabel 6, sangatlah fluktuatif dikarenakan tiga tahun berturut-turut dari tahun 2015-2017 realisasi penerimaan PBBKB tidak tercapai. Laju pertumbuhan dapat dikatakan belum berhasil.

\section{SARAN}

Saran praktis pada penelitian ini, penulis menyarankan agar Badan Pendapatan Daerah Provinsi Sumatera Selatan harus mengoptimalkan potensi pajak yang sudah ada itu menjadi lebih fungsional (intensifikasi) terhadap subjek pajak dan wajib pajak. Selain itu, Badan Pendapatan Daerah dalam kerjasama dengan Badan Pengatur Hilir Minyak dan Gas harus menjalin koordinasi, sinergi, dan harmonisasi, Karena hal ini sangat membantu untuk mengoptimalkan Pendapatan Asli Daerah melalui Penerimaan Pajak Bahan Bakar Kendaraan Bermotor (PBBKB) Provinsi Sumatera Selatan. 
Saran teoritis pada penelitian ini, disarankan untuk menambah periode penelitiannya sehingga bisa lebih detail dalam menganalisis efektivitas, kontribusi dan laju pertumbuhan pemungutan pajak bahan bakar kendaraan bermotor terhadap PAD Sumatera Selatan. Selain itu, penelitian ini hanya meneliti efektivitas, kontribusi dan laju pertumbuhan pada PBBKB, peneliti selanjutnya bisa menambahkan pajak daerah yang lain misalnya pajak hotel atau pajak restoran.

\section{REFERENSI}

Azwar, Saifuddin. (2015). Metode Penelitian. Pustaka Pelajar.

Elim, I., Ilat, V., \& Maznawaty, E. S. (2015). Analisis Penerimaan Pajak Daerah Dalam Meningkatkan Pendapatan Asli Daerah Provinsi Maluku Utara. Jurnal Riset Ekonomi, Manajemen, Bisnis Dan Akuntansi, 3(3), 906-916. https://doi.org/10.35794/emba.v3i3.9714

Ermadiani, E., DP, R. T., \& Rini, D. (2018). Analisis atas Penerimaan Pajak Bahan Bakar Kendaraan Bermotor (Pbb-Kb) dalam Menunjang Peningkatan Pajak Asli Daerah (Studi Kasus pada Badan Pendapatan Daerah Provinsi Sumatera Selatan). Jurnal Ekonomi Global Masa Kini, 9(2), 125134. http://ejournal.uigm.ac.id/index.php/EGMK/article/view/557

Fitri, F. I., \& Fajriana, I. (2016). Analisis Efektivitas dan Kontribusi Pajak Bahan Bakar Kendaraan Bermotor Terhadap Pendapatan Asli Daerah Provinsi Sumatera Selatan ( Studi Kasus Pada Badan Pendapatan Daerah Provinsi Sumatera Selatan ). 1-15.

Mardiasmo. (2018). Perpajakan (Revisi). Andi.

Rahmadani, I. (2019). EFEKTIVITAS PAJAK BUMI DAN BANGUNAN Universitas Teuku Umar Ika Rahmadani. AKBIS, 11-20.

Rahmadani, I. \& F. H. (2018). EFEKTIVITAS PAJAK BUMI DAN BANGUNAN DALAM MENINGKATKAN PAJAK DAERAH DI KABUPATEN ACEH BARAT. AKBIS, 2(2), 11-20. http://www.jurnal.utu.ac.id/jakbis/article/view/929

Samudra, A. A. (2016). Perpajakan Di Indonesia. Keuangan, Pajak dan Retribusi Daerah (Edisi 1). PT Rajagrafindo Persada. https://doi.org/2015.1472.RAJ

Supriadi, A. (2020). Analisis Potensi Pajak Hotel Dan Restoran Di Kota Tasikmalaya. Welfare Jurnal Ilmu Ekonomi, 1(1), 45-51.

Winarso, W. (2015). Analisis Penerimaan Pajak Kendaraan Bermotor Terhadap Pendapatan Asli Daerah ( Studi Kasus Pada Kantor CP DISPENDA Provinsi Wilayah Kabupaten Sukabumi II ). Seminar Nasional Dan Tren(SNIT), B-22-B-26. 